\title{
Research on Chinese Media and Communication: China and the West
}

\section{Fan Dong*}

Annenberg School for Communication and Journalism, University of Southern California, USA

\begin{abstract}
This is a content analysis of Chinese media and communication studies published in the top four Chinese journals, Association for Education in Journalism and Mass Communication, International Communication Association, National Communication Association journals, and top European journals from 1998 to 2010. Developed on previous studies, this study further explores objective of study, level of analysis, countries in comparison and author affiliation. This study strives to identify basic contours of studies on Chinese media communication in China and beyond; locate junctions and disjunctions between Chinese and Western perspectives concerning media and communication studies.
\end{abstract}

Keywords: Chinese media and communication; Junctions and disjunctions; Chinese and Western perspectives on communication studies

\section{The Historical Trajectory of Communication Studies in China}

According to Li [1], Communication as a discipline has experienced three most significant phases in China. Phase I was from 1981 to 1989 when Communication was first introduced to China with a major focus on initial conceptualization of the field. Scholars endeavored to achieve this goal by importing and translating Western, especially American Communication studies. Phase II was from 1990 to 1996, which was also the exploratory phase of Communication studies in China. Scholars strived to localize the study to meet the demand of Chinese news industry. 1997 to 2003 constitutes Phase III, the innovation and evaluation phase. Communication finally escalated to senior subject in 1998 and prospered. From 2005 to the present, the scope and scale of media and communication studies in China expanded dramatically. Media convergence, national image, media industry and Internet Communication became cutting-edge topics in the past few years [24]. During these phases, Chinese scholars have constructed their own conceptualization of "Chinese Communication". At the macro level, it refers to Communication knowledge disseminated, expanded and applied in China. At the meso level, it implies systematic integration of Communication knowledge and Chinese politics, economy, culture, history, society, education and philosophy. At the micro level, it indicates study on Chinese Communication theories, methodologies and historical trajectory [5].

However, as Shan [6] pinpointed, communication studies were born out of luck because it was neither channeled to sociology, nor immersed in information science. The only discipline that embraced this forlorn infant was journalism. Yet, according to Shan [6], Chinese Journalism ran out of steam before the birth of communication studies. This was due to the long-lasting debate on whether Journalism could be counted as an independent subject. Consequently, during the 1980's, Chinese journalism was detached from rational analysis and explanatory power. The very deed of creating pseudoscientific definitions based on empiricism as well as squaring academic thoughts into ideology is believed to contaminate communication studies from the very beginning. Worse still, Ruan [7] and $\mathrm{Ni}$ [8] suggested that the development of Communication was implicated by unprecedented employment difficulties in Chinese history. According to internal symposium held by the Ministry of Education in 2007, the structure of Chinese media industry is: 2200 or so newspapers, more than 8000 journals and magazines, about 1000 radio stations, 1000 television stations and 1000 cable television stations. Yet there were around 665 Journalism and Communication departments in China, which is ten times the size compared to ten years ago. As a result, the employment rate of graduates is constantly dropping. For example, in Shanghai, in the 1990 's, local media would hire 150 to 200 graduates annually, while in 2007 and 2008, none of the broadcasting institutions hired graduates publicly, among the top 10 newspapers, only 80 graduates were hired in two years. Among 207 graduates from Fudan University, 2007 and 2008 , only $15 \%$ pursued media professions, while the rest chose to work for enterprises. Similarly, only $40 \%$ of graduates from China's Renmin University ended up in media industry. Worse still, recruiting standards are leveled up year by year, and media at provincial or higher levels only hire graduates from Peking University, Tsinghua University, Fudan University and China's Renmin University. Furthermore, most graduates are required to work as interns for a long period of time before formal employment, but only a few managed to attain the formal contract when internship period ceased.

Apart from systematic problems, Shan [6] and Shao [9] summarized top five impediments for Communication studies in China. First of all, up till now, most Communication theories and practices are developed under Western influence and the mission of "indiginization" has never been accomplished. Therefore, the mismatch of borrowed theory and local practices are becoming more evident in various fields. Secondly, methodology system is still disorganized. Currently, three types of methodology dominate Chinese academia and each has its own problem. To begin with, the boundary between case study and pure description is still vague. Most studies only utilize Chinese examples to prove Western theories without further contemplation. Then in recent years, Chinese scholars are obsessed with quantitative methods without employing advanced statistic testing. The last type

*Corresponding author: Fan Dong, Annenberg School for Communication and Journalism, University of Southern California, USA, Tel: (213)-221-9001; E-mail: fandong@usc.edu

Received November 12, 2011; Accepted December 22, 2011; Published December 24, 2011

Citation: Dong F (2011) Research on Chinese Media and Communication: China and the West. J Mass Communicat Journalism 1:106. doi:10.4172/2165-7912.1000106

Copyright: @ 2011 Dong F. This is an open-access article distributed under the terms of the Creative Commons Attribution License, which permits unrestricted use, distribution, and reproduction in any medium, provided the original author and source are credited. 
of methodology, which is prevalent yet not fully proved scientific, is summary of personal working experience and thoughts. Thirdly, most studies are reactive and lagging behind the digital era. Fourthly, Chinese Communication studies are still shackled by ideology, especially in the field of interpersonal and organizational communication. Lastly, academic norms have not been formalized yet, thus Chinese scholars are caught in the middle of Western theories and Chinese reality.

\section{The Fabrics of Chinese Communication Studies Compared to the United States}

Given the enlightening role of American communication studies in China, Guo, Zhang and Pan [10] selected Chinese and American journals articles from 2000 to 2005, and conducted a comparative study on academic traditions in China and the United States. To begin with, $40.1 \%$ articles in Chinese journal have no research agenda, but only 0.4\% American articles lack this element. Besides, only 9.4\% Chinese articles include literature reviews, while the ratio is $78.6 \%$ in American journals. Meanwhile, $86.7 \%$ of Chinese articles do not mention any theories, while only $49.0 \%$ American articles fail to do so. Moreover, $40.4 \%$ of Chinese articles have no conclusion, while only $0.8 \%$ American articles share the same feature. Guo, Zhang and Pan [10] interpreted these observations as caused by structural differences. Most American journalism or communication journals are operated by academic associations (not any particular university); standardized, strict peer review rules are applied to these journals. However, most Chinese journalism or communication journals are run by universities or designated academic institutions. As a result, rules of thumbs outweigh academic norms which led to double standards in selection process. Additionally, communication as a mature discipline has developed steadily in the United States for many years, hence has achieved diversification and refinement. In the contrary, communication is still a toddler in China with constant change. This immature academic environment propelled descriptive, all-embracing research models. The top four topics in Chinese journals are Journalism practices (15.6\%), "communicator" (13.7\%), "Communication content" (11.4\%), "Journalism history" (10.8\%) and "self reflection" (10.4\%). In contrast, most American journals focus on "Audience and media effect" (29\%), "Communication content" (26.4\%), "Theoretical deliberation" (11.2\%) and "Communicator" (8.1), other topics are remarkably less studied with lower than 4\%. Guo, Zhang and Pan [10] pointed out that the emphasis on Journalism practices, history and Communication content reflected that Chinese Journalism and Communication studies are still in the transitional phase and haven't divested of pragmatism.

With more specific analysis on Journalism studies from 2002 to 2004, Wu [11] discovered that news practices and media management were the most popular topics. This trend was interpreted as a reaction to the conglomeration of media groups and reform of newspaper in those years. $\mathrm{Wu}$ [12] continued tracking Journalism studies from 2005 to 2006 and found out that studies on news practices still took the lead although declined compared to earlier years, at the same time, the proportion of literature on Journalism theory was scarce. Tong and Lin [13] had expressed concerns over the inadequacy of research on Journalism long before the summaries above. They listed five reasons: ideological intervention, lack of unified planning and coordination, lack of theoretical foundation; research funding shortage and publication barriers, lack of communication with foreign academic institutions. These typical problems still trouble the field of study in recent years despite common awareness among scholars [14]. Nevertheless, Wang [15] proposed that news practices deserves the crown in China because it gave birth to "the science of editing", which is considered to be China's contribution to Communication studies dated back to hundreds of years ago.

Compared to popular areas above, organizational communication, interpersonal communication, health communication, critical studies and political communication are outliers in Chinese academia. Various Chinese scholars offered explanations to this phenomenon. The most disastrous trope in Chinese academia would be critical studies. Hu [16] reviewed the development of communication studies in China in the past 10 years and showed special interest to the failure of this school. He discovered that the ideological and political atmosphere after 1989 consolidated a double standard, which is to bash foreign countries and imperialism while connive domestic bureaucracy. Liu [17] further argued that Schramm promoted his theories and won Chinese scholars' heart by paying personal visit to China and deliberately emphasizing the interrelation between Journalism and Communication to fit in the Chinese reality at that time. Consequently, Chinese scholars read Schiller's political economy analyses from Journalism tradition, and barely found anything different from Marxism, which they have been studied for decades. These elements together caused the abortion of critical studies in China. When it comes to Interpersonal Communication, Zhai [18] pointed out that "interpersonal" embodies different denotations in Chinese culture thus requires different approach. The Chinese equivalent of "interpersonal communication" (guanxi) actually refers to personal instead of interpersonal relationship. Therefore, personality is a more relevant variable than relation. Besides, it is more difficult to separate self and others in Chinese culture, hence Western theories and methods cannot be extrapolated into Chinese context.

Han [19] reviewed health communication in China in the past 12 years and found out that it is still a marginal area in communication studies, because most academic articles are published in medical, not communication journals. Similarly, major researchers in the field are from pharmacy or health professions. In terms of research agenda, too much attention has been paid to the relation between AIDS, media effects and news reports, while other topics are rarely explored. Simultaneously, the preference towards case studies results in a void of comprehensive and systematic analyses. In response to this, $\mathrm{Yu}$ and $\mathrm{Lu}$ [20] recommended 9 directions for future research:

(1) mass media and effect

(2) organizational transition

(3) interpersonal communication with patients

(4) health education and promotion

(5) environment

(6) health communication and culture

(7) special issues like AIDS, homosexuality

(8) history of health Communication

(9) crisis management

Similar to health Communication, political communication is also at the elementary phase. According to $\mathrm{He}$ [21], political communication hardly exists in Chinese context if we strictly follow Western definition. However, it has incarnated into two trajectories: public opinion studies and media effects research. From the public opinion angle, for a long period of time, political Communication in China was shackled 
by propaganda schemes. Only a selective few scholars managed to separate Party principles from public opinion. Shao [22] reported that from 1993 to 1998, out of the 604 articles on public opinion, $50 \%$ discuss how to channel public opinion, only $22 \%$ deal with the supervision function of public opinion. Fortunately, scholars are consciously restoring academic independence in recent years. Chinese scholars constructed their own concepts with Chinese characteristics according to Liu (2000). Most well-known ones are "behavioral public opinion", "circle of public opinion", "public opinion wave" and "inertia in public opinion". Yet, Liu [23] also detected four hurdles for further development. First of all, no unanimous definition has been coined up till now; secondly, descriptive rather than critical analyses inhibit the generation of knowledge; thirdly, scholars overemphasize certain theories and mistake the tree for the whole forest; lastly, lack of standardized methodology and innovative research designs. Through the media effects lens, Chinese scholars recognized the adverse effect of official propaganda based on agenda setting and the spiral of silence. Consequently, they started to search for individual and social explanations behind these phenomena in Chinese society [21].

In terms of medium under study, Chen [24] reviewed the development of Chinese Communication studies and identified the leading position of newspaper studies. He suggested shifting unbalanced emphasis and improving studies on radio and television. In the following years, the amount of studies on electronic media increased dramatically. However, Chen [25] noticed that the majority of television studies are better described as politicians' presentations rather than academic works. Therefore, the booming quantity does not lead to the elevation of research quality. Moreover, Xiang (2007) and Duan [14] argued that current educational practices fail to equip students with necessary skills due to limited faculty members with first-hand experience and tardy reaction to new trends in the society. In particular, Xiang (2007) underlined the importance of integrating traditional and new media in the digital age. Qiu and Chan [26] also noticed the tension between Chinese leaders' ambition to develop technology and their restrictions on critical research. They laid out the typology of China Internet studies (Table 1).

Moreover, they pointed out that foreign scholars are more concerned with political implications of the development and use of new media in China. Yet, almost all user statistics outside of China are

\begin{tabular}{|c|c|c|c|}
\hline $\begin{array}{l}\text { Levels of } \\
\text { analysis }\end{array}$ & $\begin{array}{l}\text { Who are the actors in } \\
\text { China's Internet } \\
\text { development? } \\
\text { (identifying agents and } \\
\text { their characteristics) }\end{array}$ & $\begin{array}{l}\text { What are they doing and } \\
\text { what has been done? } \\
\text { (studying operational } \\
\text { process and historical } \\
\text { trajectories) }\end{array}$ & $\begin{array}{l}\text { How to evaluate } \\
\text { the outcomes? } \\
9 \text { Accessing } \\
\text { the roles and } \\
\text { impact of the } \\
\text { Internet in social } \\
\text { transformations) }\end{array}$ \\
\hline Macro & $\begin{array}{l}\text { National infrastructure } \\
\text { builders, service } \\
\text { providers, and } \\
\text { regulatory entities }\end{array}$ & $\begin{array}{l}\text { National development, } \\
\text { regulations, and national } \\
\text { policy implementations }\end{array}$ & $\begin{array}{l}\text { Nationwide } \\
\text { assessment of } \\
\text { Internet projects } \\
\text { and public policies }\end{array}$ \\
\hline Meso & $\begin{array}{l}\text { Regional actors } \\
\text { (official bodies, ISPs, } \\
\text { etc), collectives, } \\
\text { industries, and online } \\
\text { diasporas }\end{array}$ & $\begin{array}{l}\text { Collective action, } \\
\text { organizational strategy, } \\
\text { interactions among/ } \\
\text { within meso level agents }\end{array}$ & $\begin{array}{l}\text { Evaluations } \\
\text { regarding specific } \\
\text { regions, domains } \\
\text { of interest and/or } \\
\text { organizations }\end{array}$ \\
\hline Micro & $\begin{array}{l}\text { User demographics } \\
\& \text { characteristics of } \\
\text { personal servers }\end{array}$ & $\begin{array}{l}\text { Patterns of adoption, } \\
\text { motivation, usage, \& } \\
\text { trends among individuals }\end{array}$ & $\begin{array}{l}\text { How Internet } \\
\text { influences and } \\
\text { becomes part of } \\
\text { individual lives }\end{array}$ \\
\hline
\end{tabular}

Table 1: Typology of China Internet studies [26]. from commercial organizations, thus may neglect user specificities and their interaction with technical interfaces or online contents.

Guo, Zhang and Pan [10] explored the difference in research framework, and came to the conclusion that American articles heavily utilize sociological $(76.2 \%)$, explanatory $(16.2 \%)$ and critical $(1.2 \%)$ frameworks, while these three together only appear in $18.6 \%$ of Chinese articles. The majority of Chinese articles employ "summary" (30\%), "strategic" (17.8\%), historical (15.7\%) and "pure reflection" (10.8\%). They considered meditative tendency among Chinese articles a historical heritage to Chinese literature which aims at pursuing the "whole knowledge" rather than piecemeal analysis. Similarly, traditional Chinese philosophy perceives instinct and self-reflexivity as a significant means to acquire knowledge thus not necessarily follows academic norms or methodology. Nevertheless, they believe this deviance from American academic tradition is essentially innovation and should be considered unique dynamic of Chinese Communication studies. It allows Chinese scholars to dive into more broad areas and generate more diversified knowledge.

To supplement the report above, Li [27] analyzed the use of methodology in the four leading Chinese Communication journals from 1995 to September, 2007. They found similar pattern that main methods are "meditative reflection" (65.4\%) and second hand data analysis (26.2\%). Quantitative methods constitute less than 6\% of the total, and among them, most only report descriptive statistics, while advanced statistics like regression and correlation are seldom implemented. Furthermore, scholars did not pay enough attention to new methods, even content analysis and controlled experiment can hardly be found in Chinese literature. Li explained four reasons for this: first of all, Western sociology originated from natural science and Aristotle's logic, but Chinese cultural tradition is founded on meditation and reflexivity. Secondly, most Chinese communication scholars were originally Journalism scholars, thus inherit Marxism tradition. Thirdly, unlike American academia which is regularly funded by foundations and non-profit organizations, Chinese academia relies on governmental or commercial entities. As a result, objectivity and pluralism are subject to political power and profits. Lastly, Talents equipped with required skills are scarce. Scholars from Journalism trope lack inter-disciplinary capabilities, while scholars from irrelevant majors lack sensitivity to communication issues.

In order to enhance our understanding of case studies in Chinese journals, Chen and Jiang (2002) analyzed the use of this method from 1990 to 2001. Their research showed that among the 80 articles employing case study, $60 \%$ of those articles did not have hypotheses or data support. Moreover, $44.6 \%$ only reported descriptive statistics, $26.1 \%$ are based on literature review, while only $23.9 \%$ use advanced statistics. Categorized by subject under study, $32.5 \%$ are about communication content, $25 \%$ focus on the audience, while $18.8 \%$ examine the medium. Audience study is believed to have special contribution to Chinese communication studies. First of all, it first introduced quantitative method to journalism and communication studies in China. Secondly, it cultivated generations of professional survey designers in different industries at all levels in China. However, the ability to improve the quality of surveys and advanced analyses tools remains a challenge for Chinese scholars [28].

\section{Studies on Chinese Communication in China and the West: Rationale and Methodology}

Although various researches have summarized major trends 
in studies on Chinese communication, only selective few took a comparative perspective. And tripled by the "American complex", existing comparatives studies are confined to American journals and academic norms. More importantly, they ignored the authorship element in their analyses which may well explain the difference as a great proportion of articles on Chinese Communication are written by Chinese authors studying abroad who have different research agendas with scholars back in China. The only study touching on this topic was Jin and Wang [29].They conducted an exclusive study to examine Chinese scholars in Chinese universities, who have been trained abroad, and they found out that although these so-called "sea-turtles" have broader outlook and produce more high-quality researches, but they are deeply constrained by bureaucracy and internecine in Chinese universities. Additionally, existing comparative pieces focus on the general trend without scrutinizing literature that deal with Chinese Communication ad hoc. Subsequently, the difference between studies on Chinese Communication in China and the West is still unknown. Furthermore, even the latest studies only traced articles dated to 2008 while trends beyond this date were left unexplored. Nevertheless, this date is essential as journals in China finally started to adopt blind review system in 2008. In order to identify basic contours of studies on Chinese media communication in China and beyond as well as to locate junctions and disjunctions between Chinese and Western perspectives concerning Chinese communication studies, content analysis was conducted to explore journals articles published in China, the United States and Europe from 1998 to 2010. The year 2008 was set as a watershed to discover changes in trends before and after it. The four leading Chinese journals below and journals published by ICA, NCA and major European institutions are selected for inquiry.

Journalism Quarterly (University News) by Fudan University. Journalism \& Communication Research (Journalism and Communication studies) by Chinese Academy of Social Science (CASS) Institute of Journalism. Journal of International Communication (International Press) by People's University of China. Modern Communication (Modern Media) by Chinese University of Communication (CUC).

These four journals were chosen as they were listed as the four "core communication journals" not only by all existing studies on Chinese communication reviewed above, but also Communication Supervision Department at Ministry of Education 2010. European journals in English with regular publication on Chinese communication and bear impact factor higher than 1.5 in Journal Citation Report 2010 were chosen here. The sampling procedure filtered news release, book review, conference or submission notices, lecture or speech notes, promulgation of governmental documents; in other words, only academic works are counted as qualified samples. Given this basic principle, for Chinese journals, strata sampling was adopted to choose all articles in every first, fourth, eighth and twelfth issue of each journal. A total of 2163 articles were included accordingly. Then considering the unequal amount of Western journals articles focusing on China exclusively, all academic works mentioning China were included in the study, which add up to 107 articles in total.

The coding sheet was built upon existing comparative studies and the attentive thematic typology of Communication studies in China suggested by Guo, Zhang and Pan [10]. A detailed description of the coding sheet and categorization standards is displayed in the appendix. Basically, each article was coded according to its research area, writing objective, theoretical framework, methodology in use, analytical level, country/region in comparison, whether it dealt with traditional or new media, which subcategory of new or traditional media was examined, publication region and author's affiliation. Two scholars coded articles independently, and calculated by Krippendorf's Alpha, the inter-coder reliability is .97. The results were presented to editors of the four leading Chinese journals and feedbacks were collected on each finding.

\section{Major Findings and Implications}

The Table 2 above shows that although Chinese journals cover more areas than Western ones, Journalism still dominates Chinese communication studies. The top four issues within media management were: competitive advantage of news group, development of newspapers, capital operation and introduction to foreign media management experience. Compared to the prosperity of these two topics, literature on Journalism theory was only one tenth of the former two (151 articles). Among them, "fourth theories of newspapers" and "professionalism" are still the main concern among Chinese scholars. The number of articles discussing capital operation and introduction to foreign media management experience increased 23\% after 2008 while articles on critical study and methodology dropped 12\% after 2008 . A new trend was the increasing interest in media law and Journalism history. However, most articles on media law remained at explanatory level without critical or experimental studies. Editors believe this is closely related to the fast growth of media industry in China in recent years and the constant changing of short-term regulations, many of which are highly controversial among consumers and even people in

\begin{tabular}{|c|c|c|}
\hline $\begin{array}{c}\text { Aspects } \\
\text { investigated }\end{array}$ & Chinese journals & Western journals \\
\hline \multirow[t]{17}{*}{ Research Area } & Broadcast Journalism (16.8) & Internet Communication (37) \\
\hline & Journalism Practices (12.7) & Mass Communication (20.4) \\
\hline & Mass Communication (10.1) & Media Industry (7.4) \\
\hline & Journalism History (11.0) & $\begin{array}{l}\text { Communication Education/ } \\
\text { Critical study (6.5) }\end{array}$ \\
\hline & Media industry (10.2) & $\begin{array}{l}\text { Media Law/ Journalism } \\
\text { Practices/Health } \\
\text { Communication (4.6) }\end{array}$ \\
\hline & Internet Communication (8.1) & $\begin{array}{l}\text { Intercultural Communication } \\
(2.8)\end{array}$ \\
\hline & $\begin{array}{l}\text { Journalism \& Communication } \\
\text { education (5.1) }\end{array}$ & Gender and Media (1.9) \\
\hline & Media law (3.4) & \multirow{2}{*}{$\begin{array}{l}\text { Public Relation theories and } \\
\text { practices (1.2) }\end{array}$} \\
\hline & $\begin{array}{l}\text { Advertising practices and } \\
\text { theories (3.2) }\end{array}$ & \\
\hline & $\begin{array}{l}\text { Introduction to Western } \\
\text { thoughts } \\
(2.8)\end{array}$ & \multirow[t]{2}{*}{$\begin{array}{l}\text { Children and Media/ } \\
\text { Methodology }(0.9)\end{array}$} \\
\hline & $\begin{array}{l}\text { Intercultural communication } \\
(2.8)\end{array}$ & \\
\hline & $\begin{array}{l}\text { Public Relation theories and } \\
\text { practices }(2.7)\end{array}$ & \multirow[t]{6}{*}{$\begin{array}{l}\text { Journalism and Communication } \\
\text { history }(0.6)\end{array}$} \\
\hline & Publishing (2.3) & \\
\hline & Critical studies (2.0) & \\
\hline & $\begin{array}{l}\text { Methodology/Political } \\
\text { Communication (0.9) }\end{array}$ & \\
\hline & $\begin{array}{l}\text { Health Communication/ } \\
\text { Gender and media }(0.6)\end{array}$ & \\
\hline & $\begin{array}{l}\text { Organizational } \\
\text { Communication/Interpersonal } \\
\text { Communication/Political } \\
\text { Communication(0.3) }\end{array}$ & \\
\hline
\end{tabular}

Table 2: Research Areas (in percentage). 
the industry. Meanwhile, case studies permeated the field but macrolevel, theoretical examinations were still rarely seen.

In terms of similarity, mass communication and media industry are shared interest for both sides. Meanwhile, a closer look at different types of traditional media under study reveals that television and newspaper are the major concern in both contexts (Table 3).

However, the concentration of television studies differs in both contexts. As an independent yet highly relevant domain within traditional media study, the art of anchoring enjoys a special status in Chinese communication studies. Television anchors are considered mouth and throat of the government thus undertake pivotal responsibilities as communicators. At the current stage, most studies in this field are still in the form of personal working experience or observations, only a small proportion of articles are constructed on theoretical frameworks. Among those, agenda setting and framing are key supporting ideas. This reality reflects challenges to television and film education in China. As editors acknowledged, most scholars on this topic were practitioners in the field without much academic training; consequently, they are more comfortable with journalistic style writing and lack the ability to build up theoretical frameworks. More importantly, the gap between traditional and new media convergence in the industry is highly noted yet rarely explored and implemented in education with low proportion of professors who have experience in both areas.

This naturally leads to the finding that Western scholars are more interested in Internet Communication in China than Chinese scholars themselves. Editors have already noticed the importance of Internet communication in China and cited Zhao qizheng's motto to encourage further studies on this topic. Zhao was the former director of the News Office at the State Department, and is currently the dean of Journalism Department at China's Renmin University. He said that although falling behind the West in many aspects, China manages to synchronize with the West in the domain of the Internet. China possesses the edge to compete with the United States because online contents require human intelligence, and that is where the population advantage stands out. Chinese people's wisdom could be stimulated as along as they are given a relatively free environment. This blueprint escalated "Internet Communication" to "key disciplinary project" under the instruction of Chinese Academy of Social Science in 2002. From 2000 to 2002, major universities like Chinese University of Communication, Peking University and Tsinghua University all launched Internet communication track within their Journalism and Communication schools. Currently, almost all Journalism and Communication schools in China have Internet communication departments [30]. In concert with Zhao's optimistic prospectus, Internet and Digital Media Research Lab conceives Internet communication as the most advanced subcategory within communication studies in China because of the following advantages: this field synchronized with the global trend thus accumulated abundant data, personal experience and close connections with relevant organizations both inside and outside of China. More importantly, this field has won the acknowledgment not only within the academia, but also across different industries.

Still, the Table 4 above exhibits different entry points to the field of Internet communication in China and the. Online contents in the form of news and discourses are the main focus in China, while Western scholars pay more attention to the application of technology at both individual and institutional levels across different industries.
Although articles on Internet communication jumped 12\% after 2008, the scope was still around traditional topics rather than the unique characters of the Internet. Homogenization and provincialism in research agenda permeate Internet communication studies in China. In order to counteract negative effects, major universities devoted themselves to cultivating the new generation of communication students with new media proficiency.

The preference over media effects, agenda setting theories is also

\begin{tabular}{|c|c|c|}
\hline Aspects investigated & Chinese journals & Western journals \\
\hline \multirow{13}{*}{$\begin{array}{l}\text { Traditional media } \\
\text { under study }\end{array}$} & Television (35.4) & Television (44.8) \\
\hline & Newspaper (29.3) & Newspaper (37.9) \\
\hline & Art of anchoring (5.5) & Magazine (3.6) \\
\hline & Advertising (5.3) & Governmental image (3.5) \\
\hline & News practices (4.8) & Spokesman system (3.4) \\
\hline & Policy (4.5) & Film (3.3) \\
\hline & Branding (3.0) & News practices (3.3) \\
\hline & Governmental image (2.8) & \multirow[t]{6}{*}{ Governmental image (3.2) } \\
\hline & Radio (2.3) & \\
\hline & Crisis management (2.0) & \\
\hline & Magazine (1.9) & \\
\hline & Film (1.7) & \\
\hline & Others (1.5) & \\
\hline
\end{tabular}

Table 3: Traditional media under study (in percentage).

\begin{tabular}{|l|l|l|}
\hline $\begin{array}{l}\text { Aspects investigated } \\
\text { New media under } \\
\text { study }\end{array}$ & \multicolumn{1}{|c|}{ Chinese journals } & \multicolumn{1}{c|}{ Western journals } \\
\cline { 2 - 3 } & Online news (36.4) & Blog (34.5) \\
\cline { 2 - 3 } & $\begin{array}{l}\text { New space for freedom of } \\
\text { speech (19.4) }\end{array}$ & $\begin{array}{l}\text { Application of technology } \\
(27.6)\end{array}$ \\
\hline & $\begin{array}{l}\text { Telecommunication (13.8) } \\
(10.1)\end{array}$ & Online news (13.7) \\
\hline & Telecommunication (6.2) & Online communities (8.0) \\
\hline Blog (5.4) & $\begin{array}{l}\text { New space for freedom of } \\
\text { speech(2.0) }\end{array}$ \\
\hline & Website (1.6) & Website(0.3) \\
\hline & Gaming (0.8) & Gaming (0.1) \\
\hline
\end{tabular}

Table 4: New media under study (in percentage).

\begin{tabular}{|c|c|c|}
\hline $\begin{array}{c}\text { Aspects } \\
\text { investigated }\end{array}$ & Chinese journals & Western journals \\
\hline \multirow{12}{*}{$\begin{array}{l}\text { Theoretical } \\
\text { Framework }\end{array}$} & Descriptive (74) & Globalization (14.0) \\
\hline & Agenda Setting (3.5) & Framing (12.1) \\
\hline & $\begin{array}{l}\text { Party Principles and } \\
\text { Marxism (3.0) }\end{array}$ & Innovation/Diffusion (11.2) \\
\hline & Media Effects (2.5) & Agenda Setting (9.3) \\
\hline & Communication Model (2.1) & Descriptive (9.0) \\
\hline & Globalization (2.0) & Social Psychology (7.4) \\
\hline & Discourse power (1.0) & Information Society (5.6) \\
\hline & Objectivity/Semiotics (0.9) & Power and Society (4.6) \\
\hline & Professionalism (0.8) & Public Sphere (3.7) \\
\hline & Public sphere/ldentity (0.6) & $\begin{array}{l}\text { Use and Gratification/ } \\
\text { Consumerism/Identity } \\
(2.8)\end{array}$ \\
\hline & Power and Society (0.4) & $\begin{array}{l}\text { Communication Model/ } \\
\text { Gatekeeper/Encoding and } \\
\text { Decoding (1.0) }\end{array}$ \\
\hline & $\begin{array}{l}\text { Other theories each less than } \\
0.1\end{array}$ & $\begin{array}{l}\text { Four Theories/Feminism } \\
(0.8)\end{array}$ \\
\hline
\end{tabular}

Table 5: Theoretical frameworks (in percentage). 
Citation: Dong F (2011) Research on Chinese Media and Communication: China and the West. J Mass Communicat Journalism 1:106. doi:10.4172/2165-7912.1000106

Page 6 of 8

evident judged by Table 5 above. Although Western scholars are more accustomed to utilizing theoretical frameworks than their Chinese cohorts, Chinese and Western literature generally cover similar theories. Among those theoretical frameworks, agenda setting is cherished by both sides. Western scholars' higher level of interest in Chinese Internet and the application of technology led to the popularity of innovation and diffusion theories. Meanwhile, the frequent use of Party principles and Marxism resonate with earlier argument that Communication studies in China are still guided by governmental agenda and reactive to official policies. The only dramatically changed theoretical framework is public sphere which increased 9\% after 2008. Editors believe the rise of public opinion on different new media outlets contributed to the change.

Although globalization is the leading theoretical framework used by Western scholars, the majority of articles both in Chinese and Western journals focus on domestic issues (Table 6). Nonetheless, when other countries are brought in for comparison, the United States is the first choice for both Chinese and Western scholars and the trend continues after 2008. An interesting phenomenon is that even if China is compared to the West in general, most of the time, authors only cite the United States as if it represents the West. With the aim of introducing different media systems in the world and assimilating experiences from other countries, Chinese journals conduct more diverse comparisons with countries across the globe. Most comparative studies are generated from comparing disputative news reports on China from foreign countries and within China so as to explore the historical and cultural causations behind them. This also explains why framing and agenda setting are frequently used by authors in China and the West too.

Case study is the favorite method for both Chinese and Western scholars, it outweighs other methods substantially (Table 7,8 ). Since

\begin{tabular}{|l|l|l|}
\hline \multicolumn{1}{|c|}{$\begin{array}{c}\text { Aspects } \\
\text { investigated }\end{array}$} & \multicolumn{1}{|c|}{ Chinese journals } & \multicolumn{1}{|c|}{ Western journals } \\
\hline $\begin{array}{l}\text { Countries in } \\
\text { comparison }\end{array}$ & None (78.8) & None (78.7) \\
\cline { 2 - 2 } & The United States (8.8) & The United States (8.3) \\
\cline { 2 - 2 } & $\begin{array}{l}\text { The general concept of the } \\
\text { West (4.0) }\end{array}$ & $\begin{array}{l}\text { The general concept of the } \\
\text { West (5.6) }\end{array}$ \\
\cline { 2 - 3 } & Japan (2.4) & Korea/Singapore/Africa (3.7) \\
\hline & Taiwan/Hong Kong (1.9) & The United Kingdom (2.8) \\
\hline & Europe (1.8) & Taiwan/Hong Kong (0.9) \\
\hline & The United Kingdom (1.0) & \\
\hline & Korea/Singapore/Africa (0.8) & \\
\hline & Australia (0.3) & \\
\hline
\end{tabular}

Table 6: Countries in comparison (in percentage).

\begin{tabular}{|c|c|c|}
\hline $\begin{array}{c}\text { Aspects } \\
\text { investigated }\end{array}$ & Chinese journals & Western journals \\
\hline \multirow[t]{9}{*}{ Methodology } & Case Study (42.5) & Case Study (43.5) \\
\hline & Descriptive (41) & Comparative Study (13.9) \\
\hline & Western Literature Review (6.5) & Content Analysis (11.1) \\
\hline & Comparative Study (4.5) & Data Analysis (9.3) \\
\hline & Chinese Literature Review (2.5) & Survey (8.3) \\
\hline & Survey (1.2) & Ethnography (4.6) \\
\hline & Content Analysis (1.0) & Discourse Analysis (3.7) \\
\hline & Visual Analysis (0.4) & $\begin{array}{l}\text { Literature Review/ } \\
\text { Interviewing (1.0) }\end{array}$ \\
\hline & Data Analysis (0.2) & $\begin{array}{l}\text { Visual Analysis/Descriptive } \\
(0.8)\end{array}$ \\
\hline
\end{tabular}

Table 7: Methodology (in percentage).

\begin{tabular}{|l|l|l|}
\hline \multicolumn{1}{|c|}{ Aspects investigated } & \multicolumn{1}{c|}{ Chinese journals } & \multicolumn{1}{c|}{ Western journals } \\
\hline Analytical level & Macro (49.8) & Micro (57.4) \\
\cline { 2 - 3 } & Micro (45.6) & Macro (38.9) \\
\cline { 2 - 3 } & Meso (4.4) & Meso (3.7) \\
\hline
\end{tabular}

Table 8: Analytical level (in percentage).

\begin{tabular}{|c|c|c|}
\hline $\begin{array}{c}\text { Aspects } \\
\text { investigated }\end{array}$ & Chinese journals & Western journals \\
\hline \multirow{17}{*}{ Research Objective } & $\begin{array}{l}\text { Improve Practical Skills } \\
(15.8)\end{array}$ & Theorization (39.8) \\
\hline & $\begin{array}{l}\text { Intro to Western media } \\
\text { system }\end{array}$ & $\begin{array}{l}\text { Sociological analysis of new } \\
\text { media (24.1) }\end{array}$ \\
\hline & $\begin{array}{l}\text { Strategies to domestic } \\
\text { crisis or reform }(9.2)\end{array}$ & Policy making (8.3) \\
\hline & $\begin{array}{l}\text { Historical examination } \\
(9.1)\end{array}$ & $\begin{array}{l}\text { Education improvement } \\
(5.7)\end{array}$ \\
\hline & $\begin{array}{l}\text { Intro to Western } \\
\text { theories }(7.2)\end{array}$ & $\begin{array}{l}\text { Strategies to } \\
\text { misunderstandings and } \\
\text { misrepresentation in } \\
\text { intercultural communication } \\
(5.5)\end{array}$ \\
\hline & Theorization (5.4) & Improve Practical Skills (4.6) \\
\hline & $\begin{array}{l}\text { Summary or prospectus of } \\
\text { the field (5.3) }\end{array}$ & Media and Society (2.8) \\
\hline & $\begin{array}{l}\text { Sociological enquiry of } \\
\text { new media environment } \\
(5.1)\end{array}$ & $\begin{array}{l}\text { New media and democratic } \\
\text { process }(2.0)\end{array}$ \\
\hline & $\begin{array}{l}\text { Education improvement } \\
5.0 \text { ) }\end{array}$ & $\begin{array}{l}\text { Summary or prospectus of the } \\
\text { field (1.8) }\end{array}$ \\
\hline & $\begin{array}{l}\text { Strategies to international } \\
\text { challenge/Introduction to } \\
\text { prominent institution and } \\
\text { person (3.5) }\end{array}$ & Media Convergence (1.1) \\
\hline & Media and society (3.0) & $\begin{array}{l}\text { Introduction to prominent } \\
\text { institution and person (1.0) }\end{array}$ \\
\hline & $\begin{array}{l}\text { Strategies to } \\
\text { misunderstandings } \\
\text { and misrepresentation } \\
\text { in intercultural } \\
\text { communication (2.9) }\end{array}$ & $\begin{array}{l}\text { Strategies to domestic crisis or } \\
\text { reform }(0.8)\end{array}$ \\
\hline & Economic analysis (2.5) & Strategies to international \\
\hline & $\begin{array}{l}\text { Audience behavior/ } \\
\text { psychology (2.4) }\end{array}$ & \\
\hline & Media convergence (1.2) & \\
\hline & External propaganda (1.1) & \\
\hline & $\begin{array}{l}\text { New media and } \\
\text { democratic process }(0.4)\end{array}$ & \\
\hline
\end{tabular}

Table 9: Research Objective (in percentage).

Chinese Communication studies are struggling to build up its own structure and system, reviewing Western literature became a crucial part of this project. An important trait of Chinese methodology has been reiterated many times earlier, that is, description of phenomenon, instant issues and personal thoughts. Editors intentionally controlled the proportion of these types of articles after 2008 yet they still take up around $50 \%$ of all articles published. A more nuanced examination of the data reveals that although case study is the most important method for both Chinese and Western scholars, they analyze communication issues with different perspectives. Chinese scholars prefer macro level analysis, while Western scholars prefer micro level examination. Meso analyses are rarely found in both contexts. The general preference for macro analyses in China results from the wholistic epistemology and research objective and this trend did not change significantly before and after 2008. 


\begin{tabular}{|c|c|}
\hline $\begin{array}{l}\text { Aspects } \\
\text { investigated }\end{array}$ & Western journals \\
\hline \multirow{13}{*}{$\begin{array}{l}\text { Authors' Affiliation } \\
\text { in Western } \\
\text { Journals }\end{array}$} & $\begin{array}{l}\text { Chinese scholars from American university published in } \\
\text { American journal (21.3) }\end{array}$ \\
\hline & $\begin{array}{l}\text { Chinese scholars from Chinese university published in } \\
\text { European journal (16.7) }\end{array}$ \\
\hline & $\begin{array}{l}\text { Chinese scholars from American university published in } \\
\text { European journal (14.8) }\end{array}$ \\
\hline & $\begin{array}{l}\text { European scholars from European university published in } \\
\text { American journal (11.1) }\end{array}$ \\
\hline & $\begin{array}{l}\text { American scholars from American university published in } \\
\text { American journal (7.4) }\end{array}$ \\
\hline & $\begin{array}{l}\text { European scholars from European university published in } \\
\text { European journal (6.5) }\end{array}$ \\
\hline & $\begin{array}{l}\text { Co-authored by Chinese and American scholars from } \\
\text { American university published in American journal (5.6) }\end{array}$ \\
\hline & $\begin{array}{l}\text { Chinese scholars from European university published in } \\
\text { European journal (5.6) }\end{array}$ \\
\hline & $\begin{array}{l}\text { Australian scholars from Australian university published in } \\
\text { European journal (4.6) }\end{array}$ \\
\hline & $\begin{array}{l}\text { Chinese scholars from Chinese university published in } \\
\text { American journal (1.9) }\end{array}$ \\
\hline & $\begin{array}{l}\text { Australian scholars from Australian university published in } \\
\text { American journal }(0.9)\end{array}$ \\
\hline & $\begin{array}{l}\text { Singapore scholars from Singapore university published in } \\
\text { European journal (0.9) }\end{array}$ \\
\hline & Others $(0.9)$ \\
\hline
\end{tabular}

Table 10: Author's affiliation in Western journals (in percentage).

The pragmatic and theoretical divide between Chinese and Western scholars extends beyond their choices of research areas, methodology, theoretical frameworks. The Table 9 below illustrates that the main purposes of Chinese studies are to improve practical skills, introduce Western media system, and stipulate strategies to domestic crisis or reform. Theorization only accounts for $5.4 \%$ of all types of research objectives. After 2008, theorization increased slightly by $2.1 \%$ with the majority reviewing Western studies. The pragmatic orientation of Chinese communication research further explains why macro level lens are adopted to map out the whole picture. In contrast, theorization is the main focus for Western scholars, while the enthusiasm for Internet Communication attracts them to analyze new media from sociological angle. Improving practical skills only takes up $4.6 \%$ of the whole spectrum. Strategies to misrepresentation and misunderstandings in international communication draw attention from both sides; this is also where comparative studies show their strength. Editors suggest that compared to the mature media system in the West, China is experiencing changes so fast and exciting that leave scholars no time for meditation. More importantly, with strict requirements on publication in the current promotion system as well as funding pressure in China, pragmatic topics bring success more easily than theoretical pieces.

Last but not the least, the Table 10 above shows that the backbone of scholars studying Chinese Communication in the West is still Chinese scholars either trained abroad or within China(the majority are from Hong Kong), they take up $50.9 \%$ of the total; if co-authored articles are included, the ratio is $58.4 \%$. This ratio stayed steady before and after 2008. Chinese scholars affiliated to Chinese universities are more inclined to submit to European rather than American journals. This may be related to the higher ratio of articles about China in European journals which suggests that European scholars are generally more interested in Chinese Communication than their American counterpart. Additionally, scholars from Australian and Singapore are also active in this field. Since most Chinese scholars were still in their budding phase when they returned to China, their resolution to secure a place in English publications is vulnerable to the academic environment in China. In terms of areas under study, American scholars are more interested in mass communication and education problems in China, while European scholars are more interested in Internet Communication in China.

So far, we found out that Chinese scholars prefer macro-level studies and have a particular interest in the pragmatics of journalism and communication. This trend extends to the application of methodologies and theories despite the effort to improve the diversity of articles after the execution of blind review in 2008. Creating standardized research norms has been considered the single most important task among Chinese scholars at the current stage. In contrast, Western scholars focus on micro-level studies and show greater interest in new media technology and media policy in China. A broader variety of conceptual and methodological tools is deployed more Western scholars. We also identified academic tradition and environment, cultural heritage, developmental trajectory of Communication discipline, social and political intervention as major contributors to the differences discovered above. Further qualitative studies among Chinese scholars and journal editors are needed to better understand how the current status quo is formed and developed in the Chinese soil. Moreover, qualitative studies on foreign scholars' perspective and interpretation on this issue should also be developed for us to further explore research differences in these two contexts.

\section{Acknowledgment}

The author would like to thank Ernest Wilson and Jay Wang who helped framing the study and organize USC Annenberg Colloquium on China Media Studies.

\section{References}

1. Li XR (2005) Communication studies from Chinese bibliography. Modern Communication.

2. Chen LD, Wang L (2007) A Review on the Studies of Journalism and Communication studies in China in 2006. Journal of International Communication.

3. Chen LD, Che XY (2008) Review of Journalism and Communication studies in 2007. Journal of International Communication.

4. Chen LD (2011) Interpreting Chinese Communication studies. People's Daily Publishing House.

5. Zhang J (2008) Chinese Communication: conceptual evolution and analysis of its connotation. Journal of International Communication.

6. Shan B (2008) How to exhibit Chinese wisdom in Communication studies? Journalism Quarterly.

7. Ruan ZhX (2005) Development, education and employment issues of Communication. Journal of Southwest Minzu University.

8. Ni YN (2010) Phase theory of Chinese Journalism. Journalism and Communication Research.

9. Shao RP (2010) Communication status and trajectory in China. Modern Communication.

10. Guo K, Zhang JF, Pan J (2008) Comparison of American and Chinese academic traditions in Journalism and Communication studies. Journalism Quarterly.

11. Wu F (2005) Summary of Journalism studies from 2002 to 2004. Modern Communication.

12. Wu F (2007) Summary of Journalism studies from 2005 to 2007. Modern Communication.

13. Tong B, Lin $H$ (2001) One hundred years of Chinese journalism: a review. Journalism and Communication Research. 
Citation: Dong F (2011) Research on Chinese Media and Communication: China and the West. J Mass Communicat Journalism 1:106. doi:10.4172/2165-7912.1000106

Page 8 of 8

14. Duan B (2011) Comparison on Chinese and American Communication education.Modern Communication.

15. Wang ZhD (2007) The science of editing: Communication theory with Chinese character. Journalism and Communication Research.

16. Hu YQ (2008)Reconsidering on the "abortion" of critical school. Journal of International Communication.

17. Liu HL (2007) The missing person in Chinese Communication studies: early Communication thoughts from the introduction of critical school, 1978-1989. Journalism and Communication Research.

18. Zhai XW (2008) Local interpersonal communication: the "guanxi" perspective ad theoretical orientation. Journalism and Communication Research.

19. Han G (2004) Absence of Communication researchers: 12 years' studies of health Communication in Mainland China. Journalism and Communication Research.

20. Yu GM, Lu F (2011) The historical development and current status of Health Communication in China. Modern Communication.

21. He Zh (2008) The trajectory of political Communication in China. Journalism Quarterly.

22. Shao PR (2002) Journalism studies in the $20^{\text {th }}$ century: public opinion and propaganda. Fudan University Publishing House.

23. Liu JM (2010) The achievements of public opinion studies in the new century. Journalism and Communication Research.

24. Chen LD (2000) Outlook on Chinese Communication studies at the beginning of the century. Journalism and Communication Research.

25. Chen LD (2005) Contemporary Journalism studies and problems. Journalism and Communication Research.
26. Qiu LCH, Chan J (2004) China Internet Studies: A review of the field, In Helen Nissenbaum and Monroe Price. (eds)The Academy and the Internet: Peter Lang Publishing, New York.

27. Li B (2008) The structure of Journalism and Communication methodology, observation on four leading journals from 1995 to 2007 . Journal of International Communication.

28. Xu YK (1998) Remarks on Communication studies in China. Journalism and Communication Research.

29. Jin JB, Wang ShSh (2003) Caught between globalization and localization: sea turtles' research path in China. Journalism and Communication Research.

30. Internet and digital media research lab (2004), Development of Internet Communication. Journalism and Communication Research.

31. Zhang ZL (2004) what is health Communication for: nine healthy research directions. Journalism and Communication Research.

32. Zhou T (2005) International Communication studies in China and problems. Journal of International Communication.

33. Wang L (2002) Journalism education in the Internet age. Journalism and Communication Research.

34. Duan JS (2008) The dilemma of Communication research in China. Journalism Quarterly.

35. Chen KY, Jiang Y (2002) Progress and weakness of case studies in China: statistical analysis of case studies in the 1990's. Journalism and Communication Research. 